\title{
Geomorphological, Geological and Engineering Geological Aspects for Sustainable Urban Planning of Mymensingh City, Bangladesh
}

\author{
Salma Akter ${ }^{1}$, Reshad Md. Ekram Ali², Shahtaj Karim¹, Mahmuda Khatun², \\ Mohammad Feruj Alam ${ }^{1}$ \\ ${ }^{1}$ Geological Survey of Bangladesh, Dhaka, Bangladesh \\ ${ }^{2}$ Jahangirnagar University, Dhaka, Bangladesh \\ Email: *salma.akter_gsb@yahoo.com
}

How to cite this paper: Akter, S., Md. Ekram Ali, R., Karim, S., Khatun, M. and Alam, M.F. (2018) Geomorphological, Geological and Engineering Geological Aspects for Sustainable Urban Planning of Mymensingh City, Bangladesh. Open Journal of Geology, 8, 737-752.

https://doi.org/10.4236/ojg.2018.87043

Received: May 16, 2018

Accepted: July 28, 2018

Published: July 31, 2018

Copyright $\odot 2018$ by authors and Scientific Research Publishing Inc. This work is licensed under the Creative Commons Attribution International License (CC BY 4.0).

http://creativecommons.org/licenses/by/4.0/

(c) $\underset{\mathrm{EY}}{\mathrm{EP}}$ Open Access

\begin{abstract}
Geomorphological, geological and engineering geological information is used as the base data to characterize the subsurface condition and for sustainable urban planning and development of the rapidly expanding Mymensingh city. Extensive field work has been completed to get the realistic scenario, data and samples have been collected from surface and subsurface with auguring and geotechnical boring. The laboratory tests have been performed following standard laboratory procedures. Geomorphologically the area is broadly classified into Older Floodplain or Mymensingh Terrace and Younger Floodplain. These two flood plains are separated by Old Brahmaputra River. Geologically the area is mainly covered by the recent alluvial flood plain deposits which are underlain by the Pleistocene Madhupur clay deposits. The Younger Flood Plain deposit consists of mainly unconsolidated fine to medium sands with some silt and clay whereas the Older Flood Plain deposits are mainly consisting of silty clay and fine to medium sand. Moderately compacted sediments of older flood plain deposit are suitable for urban development. Based on geotechnical characteristics and the $\mathrm{N}$ values (blow counts of Spontaneous Penetration Test, SPT) of the subsurface sediments, the study area is classified into four Engineering Geological Units. Unit I indicates loose soil and is suitable for shallow foundation. Unit II is indicating compact soil packing; $\mathrm{N}$ value of these two units increase with depth and would be good for heavy foundation. Unit III is suitable for shallow structures. Unit IV, which is composed of mostly clay, silty clay and sand with highly compressive organic clay, is recommended to avoid any heavy construction and could be used as open place, water retaining zone etc. Beside the geological and engineering geological study details hydrology and hydrogeological and a systematic study on seismic hazards are strongly recommended before planning of urban area.
\end{abstract}




\section{Keywords}

Geology, Engineering Geology, Standard Penetration Test (SPT)

\section{Introduction}

The need and importance of geological and engineering geological information and their role in urban planning have been highlighted with many examples from around the world (e.g. Berhane, 2012 [1]; Anderson, 2006 [2]; Bathrellos et al., 2008 [3], 2011 [4]; De Abreu and Filho, 2011 [5]; Legget, 1973 [6]; Pueyo-Anchuela et al., 2011 [7]; El May et al., 2010 [8]; Culshaw and Price, 2011 [9]). In Bangladesh the practices of using geological and engineering geological study before urban planning were ignored in past decades. Nowadays, the need for geological studies of the ground before initiating large-scale works is fully recognized after experiencing some bad incident for example in 2005 a nine-story commercial building collapsed (Spectrum garment factory) in Savar Upazila of Dhaka, an eight-story commercial building (Rana plaza) failures at Saver in 2016, a 4-story building collapsed at Begunbari of Dhaka in 2006 points to the necessity of the study of subsurface soil condition and other geological condition before planning of engineering construction. Now, the requirements of geological and engineering geological data are an obligatory part of engineering practice. However, Mymensingh is one of the fastest growing city of Bangladesh which is close to the capital Dhaka and is developing rapidly both industrially as well as agriculturally. In fact, Mymensingh City can be a home of daily Dhaka going people. The aim of the study is to provide geomorphological, geological and engineering geological data prior to develop Mymensingh city plan. For proper urban planning of the city these sub-surface parameters of the area could help for the future detail planning of the Mymensingh as mega city. This would ultimately reduce the population pressure on the Dhaka City.

The study area overlies the eastern part of the Indian Plate, which is subducting beneath the Eurasian plate to the north and being over ridden by the Burma plate to the east (Alam, 2008) [10]. A major expression of the movement is the Dauki fault, which separates the rapidly subsiding Sylhet trough, and the rapidly rising Shillong massif and Tertiary rocks that are being thrust south up into the Sylhet trough. The Burma plate impinging on the Sylhet trough from the east has produced the accurate pattern forming the Indo-Burma Ranges and the Tripura-Chittagong fold belt; deformation is propagating westward. Geophysical studies (Seeber and Armbrewster, 1981) [11] show that the folds continue north in the subsurface to the structural zone of the Dauki fault. According to the Coleman (1969) [12] the Brahmmaputtra was flowing southeast at the north end of the Madhupur tract emptied into the Meghna river before a major earthquake occurred in 1762. The study area lies south of the west end of the Shillong massif between the Sylhet trough to the east and the Jamuna River to the west (Figure 1). 


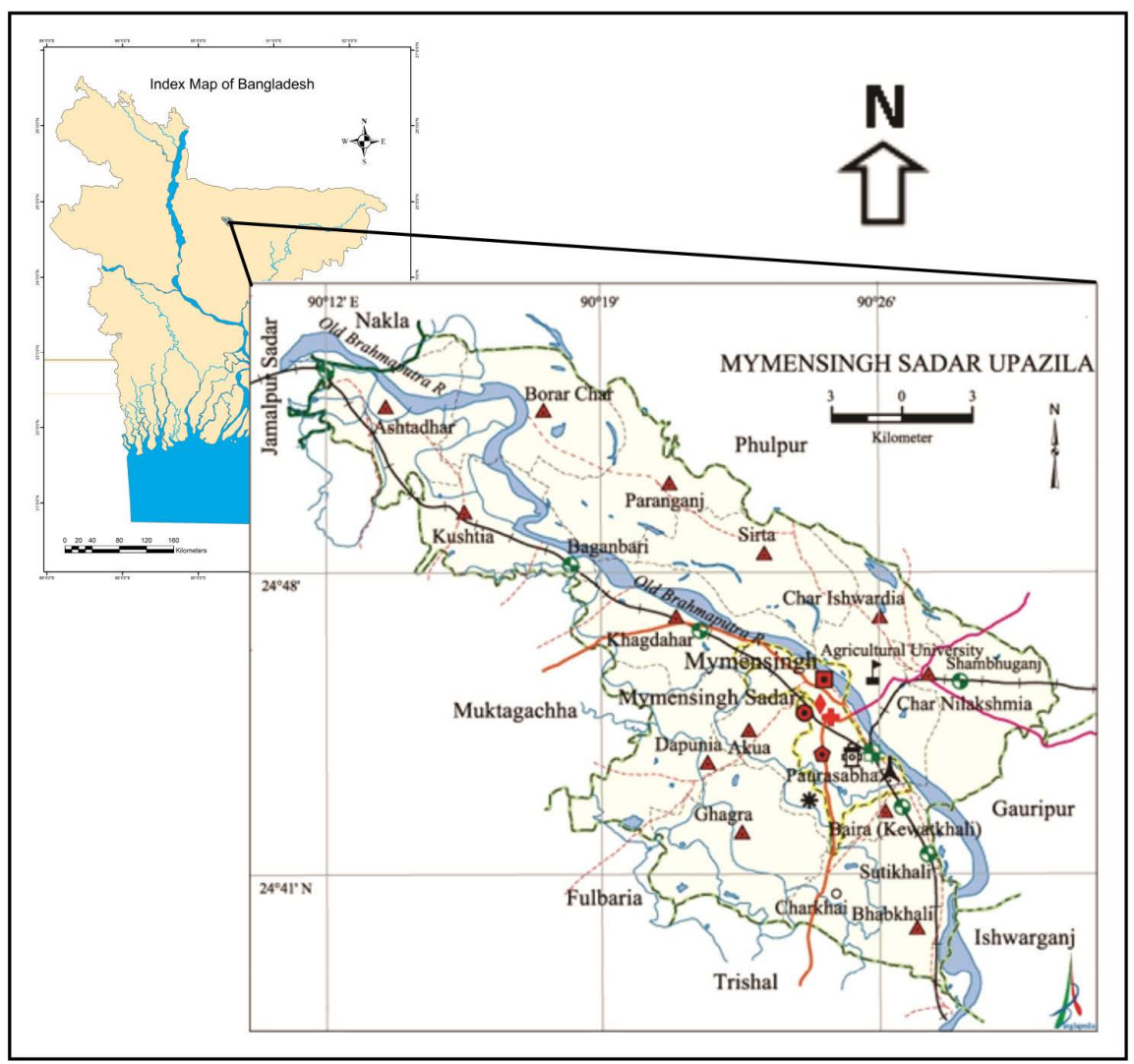

Figure 1. Location map of Mymensingh Pourashava and surrounding areas.

The area of the Mymensingh Pourashava is about 21.73 sq. km. Because of the Old Brahmaputra River, the area is mainly dominated by fluvial landforms and deposits. The mapped area lies between longitude $90^{\circ} 18^{\prime} 9^{\prime \prime} \mathrm{E}$ to $90^{\circ} 28^{\prime} 49^{\prime \prime} \mathrm{E}$ and latitude $24^{\circ} 40^{\prime} 3^{\prime \prime} \mathrm{N}$ to $24^{\circ} 48^{\prime} 37^{\prime \prime} \mathrm{N}$ and covered by the Survey of Bangladesh Topographic sheet no $78 \mathrm{~L} / 5 \& 78 \mathrm{~L} / 6$ in the scale of $1: 50,000$. The total mapped area is about 173.23 sq. $\mathrm{km}$.

The study discloses the general geomorphology, geological and engineering geological characteristics of Mymensingh city and adjoining areas. The purpose of the study is to fulfill the requirements of geological, geomorphological and geotechnical data for urban planner as well as the engineers, urban geologists, policy makers for sustainable environmental management and future perspective planning of the city.

\section{Methods of Study}

By using 1:40,000 scale aerial photographs of 1955 and topo sheets of Survey of Bangladesh no 79 I/5 and 79 I/6 photo-morphological and photo-geological maps have been prepared. Extensive field work has been completed to get the practical scenario of geomorphology and surface geology. In the field, these remotely sensed data/units (surface geology and geomorphology) were checked by physical verification. Some units were changed after field checking; in some cas- 
es, two or more units were merged into one unit or new units were added. For investigation of sub-surface geology, 20 standard penetration test (SPT) borings in different geomorphological units at various locations of the cities up to $30 \mathrm{~m}$ depth were performed. Regular auguring at maximum depth 5 meter was carried out simultaneously. To identify geotechnical properties of rocks/soils spatially as well as vertically soil/rock samples were collected from these boreholes for further test in the laboratory. Grain size analysis, moisture content, unit density, specific gravity, Atterberg limit, direct shear test for some selected samples were performed in laboratory.

Grain size distribution is a quantitative determination of the distribution of particle sizes in soils. US standard sieves from 6 (3.36 $\mathrm{mm}$ opening) to 200 ( $0.074 \mathrm{~mm}$ opening) were arranged to follow 0.25 phi interval for recording precise grain size data. The distribution of particle sizes larger than 75 micrometers or $0.075 \mathrm{~mm}$ (retained on the No. 200 sieve) is determined by dry sieving, while the distribution of particle sizes smaller than 75 micrometers is determined by a sedimentation process using a hydrometer. Humboldt sieving machine was used in the laboratory to conduct grain size investigation.

To conduct the laboratory investigation and determine the plastic and liquid limits of fine-grained soil standard, procedures described in ASTM 4318 were followed. The liquid limit (LL) is the water content, in percent, at which a portion of soil in a standard cup and cut by a groove of standard dimensions will flow together at the base of the groove for a distance of $13 \mathrm{~mm}(0.5 \mathrm{in}$.) when subjected to 25 shocks from the cup being dropped $10 \mathrm{~mm}$ in a standard liquid limit apparatus operated at a rate of two shocks per second. The plastic limit $(\mathrm{PL})$ is the water content, in percent, at which a soil can no longer be deformed by rolling into $3.2 \mathrm{~mm}$ (1/8 in.) diameter threads without crumbling. ASTM D 4318 was used to determine Atterberg limits for liquid limit (LL), plastic limit (PL, measured in percentage), and plasticity index (plasticity index PI $=\mathrm{LL}-\mathrm{PL}$, also measured in percentage) in order to assess the geotechnical properties of several layers from $-5 \mathrm{~m}$ extending to $-30 \mathrm{~m}$. Both disturbed and undisturbed samples were used.

The presence and percentage of organic matters were calculated with visual inspection during field work. The presence of organics in soils is generally associated with high compressibility, significant secondary compression, often unsatisfactory strength characteristics, and low unit weight.

SPT or blow counts were retrieved from the daily log prepared by the site geologists and recorded in paper to conduct geoengineering investigation. SPT (standard penetration test) or $\mathrm{N}$ (blow counts) was performed by using a $64 \mathrm{~kg}$ (140-pounds) hammer and letting it free-fall for $76.2-\mathrm{cm}$ (30 inches) with a $15.2-\mathrm{cm}$ interval (6-inch), reaching a maximum depth of $61-\mathrm{cm}$ (24 inches). For better accuracy of estimating $\mathrm{N}$ values, only second $30-\mathrm{cm}$ (12-inch) and third $46-\mathrm{cm}$ (18-inch) measurement were used in this research. The value recorded for the first round of advance is usually discarded because of fall-in and contamina- 
tion in the borehole. This value is reported as the SPT blow count value, commonly termed "N". After the penetration test is completed, the sampler is retrieved from the hole. The split barrel is opened, the soil is classified, and a moisture specimen is obtained. After the test, the borehole is extended to the next test depth and the process is repeated. SPT soil samples are disturbed during the driving process and cannot be used as undisturbed specimens for laboratory testing. Finally, on the basis of geomorphological, geological and geotechnical properties, an engineering geological map has been prepared. Software like ArcGIS 10, Rock works, Surfer 8.3 and Adobe Photoshop 7.0 are used for preparing maps and logs.

\section{Results and Discussion}

\subsection{Geomorphological Analysis}

Physiographically, Mymensingh Pouroshava and adjoining areas is situated mainly on the Mymensingh Terrace. Alam et al. (2008) [10] marked the area in between Brahmaputra and Madhupur Tract as Mymensingh Terrace which is nearly flat surface and stands above flood level. The study area comprises with two flood plains named Mymensingh Terrace/Old flood plain and Younger flood plain. Mymensingh Terrace is situated in the southern part of the Brahmaputra River and Younger flood plain is situated in the northern part of the Brahmaputra River (Figure 2). Terrace is featured by point bar, lateral bar, natural levee, floodplain, flood basin, depression, ox-bow lake and abandoned channel. The younger flood plains are flat, except for the relief produced by natural levee, point bar, lateral bar, flood basin, depression; abandoned channel etc. Natural levees are comparatively elevated than bars and depressions. For proper site selection for urban planning high land can get the priority. The elevation of the area varies from $8.23 \mathrm{~m}$ to $15.25 \mathrm{~m}$ above Public Works Datum (PWD) reference Level. The drainage system has dendritic pattern (Figure 2). Brahmaputra, Sutia and Barrera are the main river. The study area also comprises some beels or low lying areas which are marshy in nature.

\subsection{Geological Analysis}

Mainly, the entire area is broadly divided into Older Floodplain Deposits and Younger Floodplain Deposits. After that, classification and characterization of these two units was carried out details. The geological subunits have been established on the lithological characteristics gathered through auger hole and the bore logs; distributed over different geological and geomorphological units. The study reveals that the area is covered by the recent alluvial flood plain deposits which are underlain by the Pleistocene Madhupur Clay deposits. Based on the lithological properties, a geological map and a cross-section have been drawn along A-B line at north-south direction (Figure 3(a) \& Figure 3(b)). It has been noticed that a silty clay rich layer of around 5 to 10 meter thick at the center and southern part is underlain by thick silty sand $10 \mathrm{~m}$ to $15 \mathrm{~m}$ thick, followed by 4 
BOREHOLE \& AUGUR LOCATION ON CEOMORPHO;OGICAL MAP OF MYMENSINGH PAURASHAVA AND SURROUNDINGS

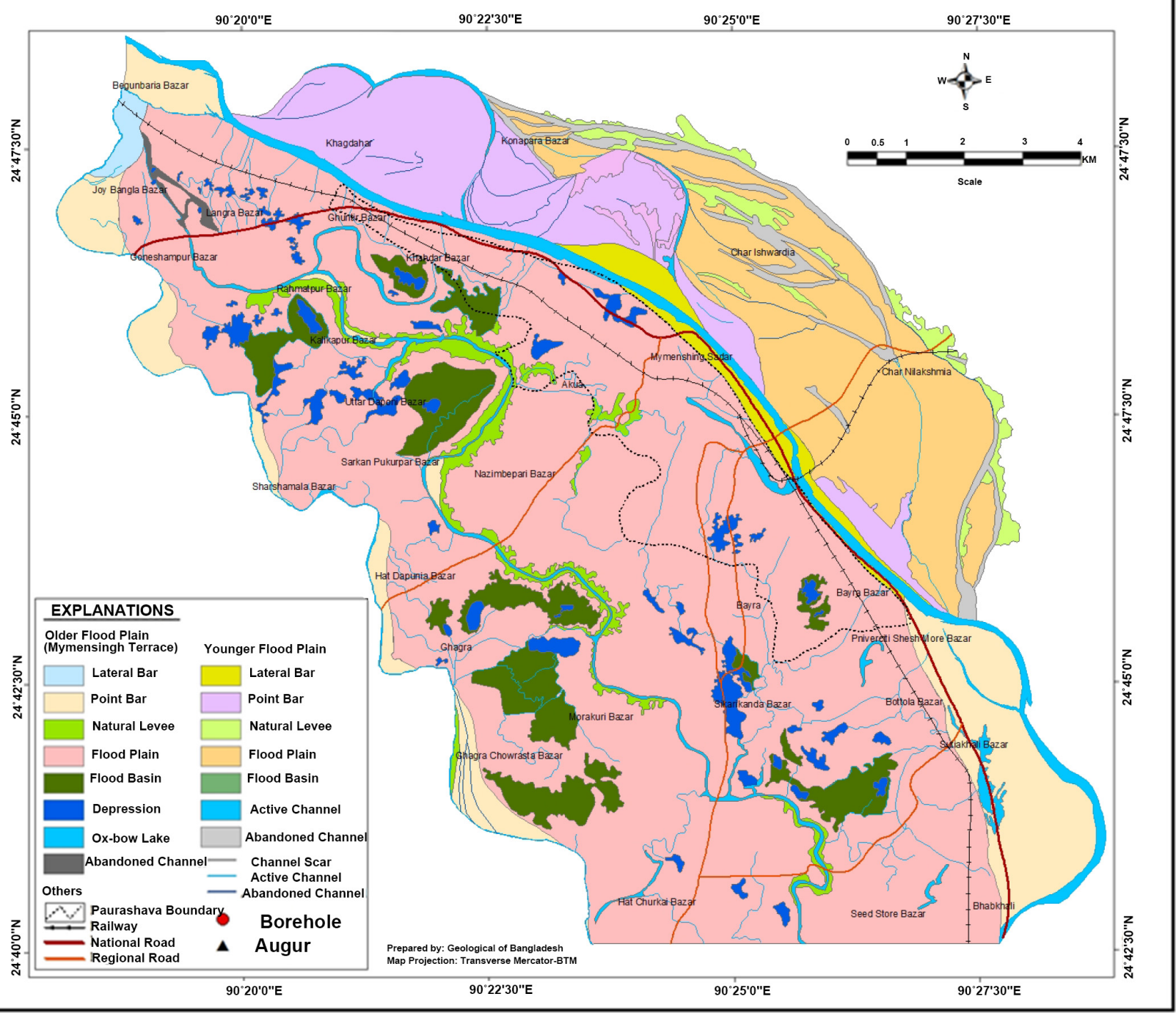

Figure 2. Geomorphological map of Mymensingh Pourashava and surrounding areas.

$\mathrm{m}$ to $10 \mathrm{~m}$ thick silty clay layer. This layer again is underlain by fine sand sediments of variable thicknesses. Borehole spacing is variable ( $2 \mathrm{~m}$ to $6 \mathrm{~m})$.

\subsubsection{Old Flood Plain Deposits (Mymensingh Terrace)}

Bar deposit of older flood plain mainly consists of alteration of very fine sand, medium sand, sandy silt and clayey silt deposit along the river channel. Medium sand are light gray in color, sub rounded to rounded having mica which percentages are about $5 \%$. Very fine to fine sands are grey in color with presence of mica ( $1 \%$ to $5 \%$ ). Clayey silts are greyish brown colored, slightly oxidized; rootlets are found in this bed (Figure 4(b)).

On the other hand, natural levee deposits are sequences of cyclically bedded, fining upward beds into silty clay to clay. The basal bed of each natural levee deposits is of more or less $2 \mathrm{~m}$ thick fine sand bed which is followed by 3 to $8 \mathrm{~m}$ thick light olive brown to greenish black silty clay and light bluish grey clay to 


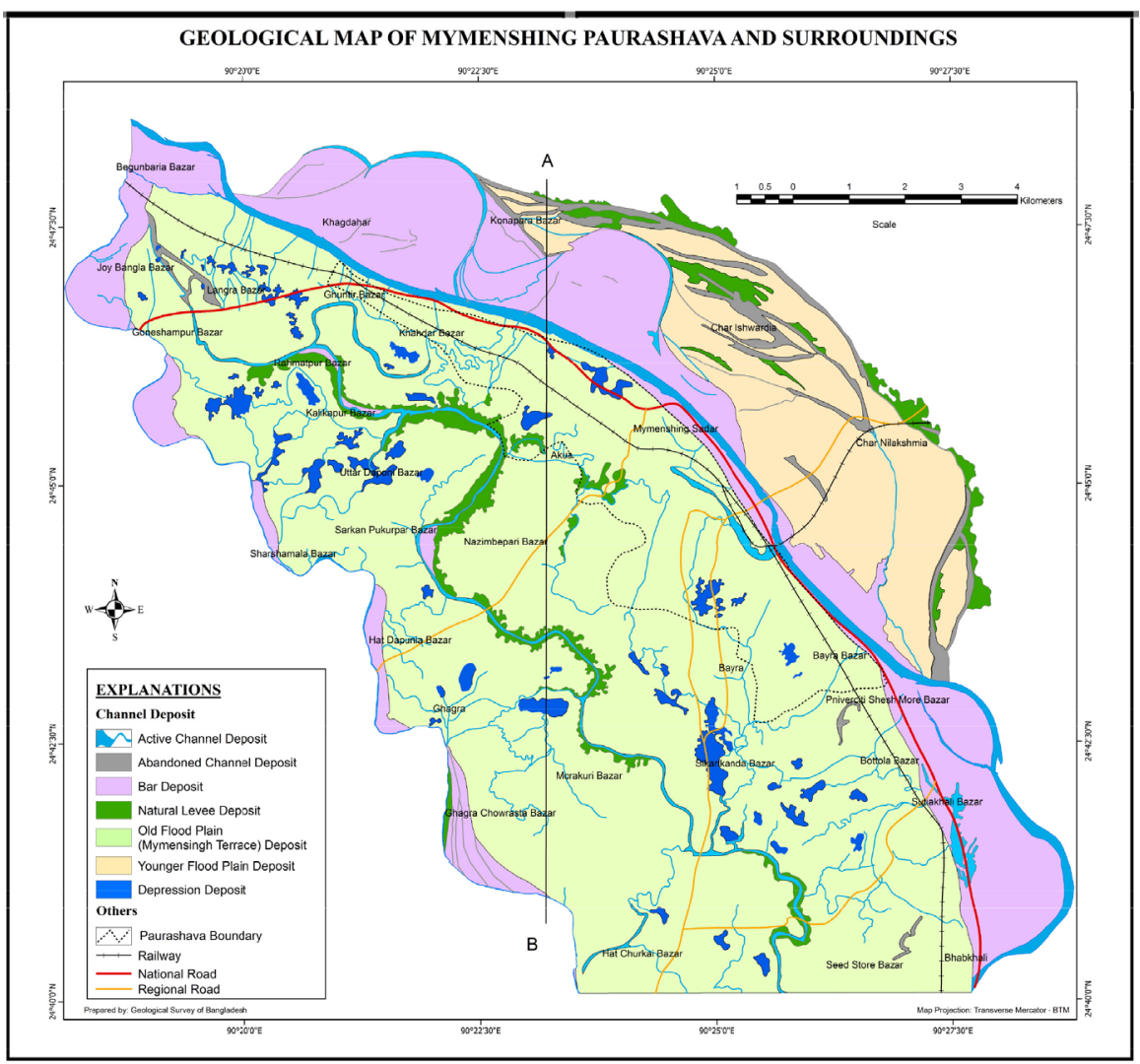

(a)

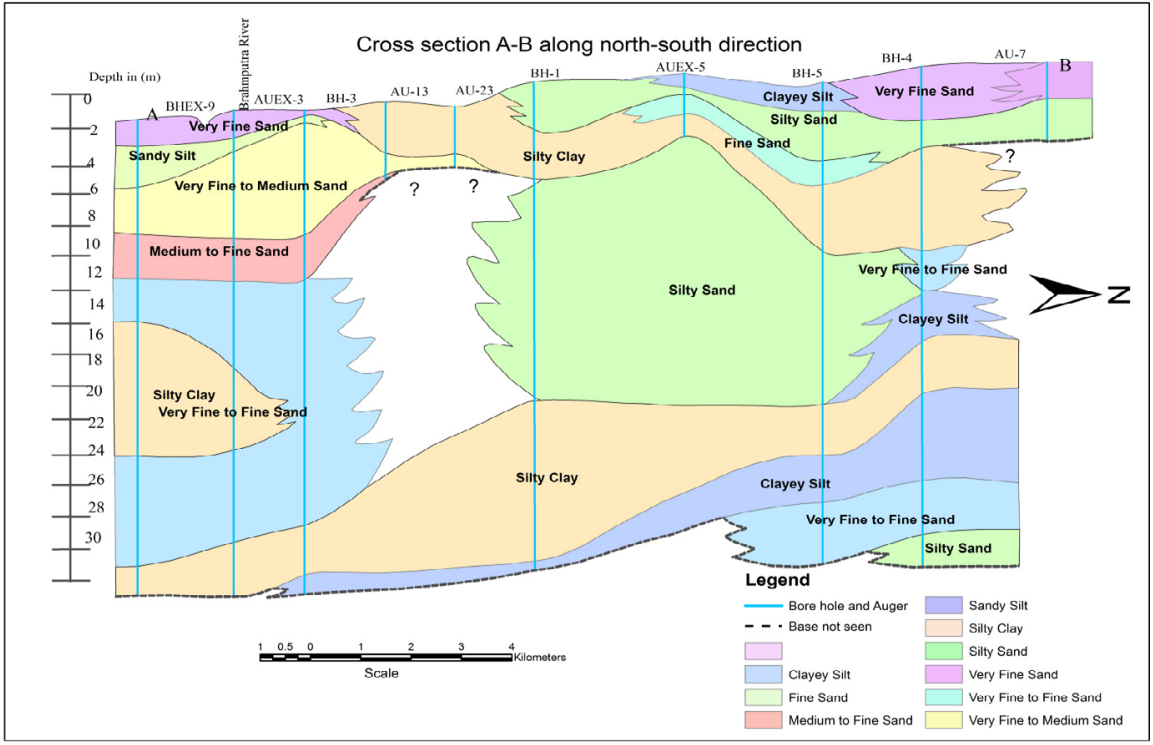

(b)

Figure 3. Geological map (a) and schematic cross section along A-B (b) of Mymensingh Pourashava and adjoining areas.

greenish black sticky clay beds. Fine sands are olive brown in color with mica concentration; the percentage is about $10 \%-20 \%$. Deposits are as thick as $2 \mathrm{~m}$ adjacent to the channel and thin outward to merge into flood plain, flood basin 


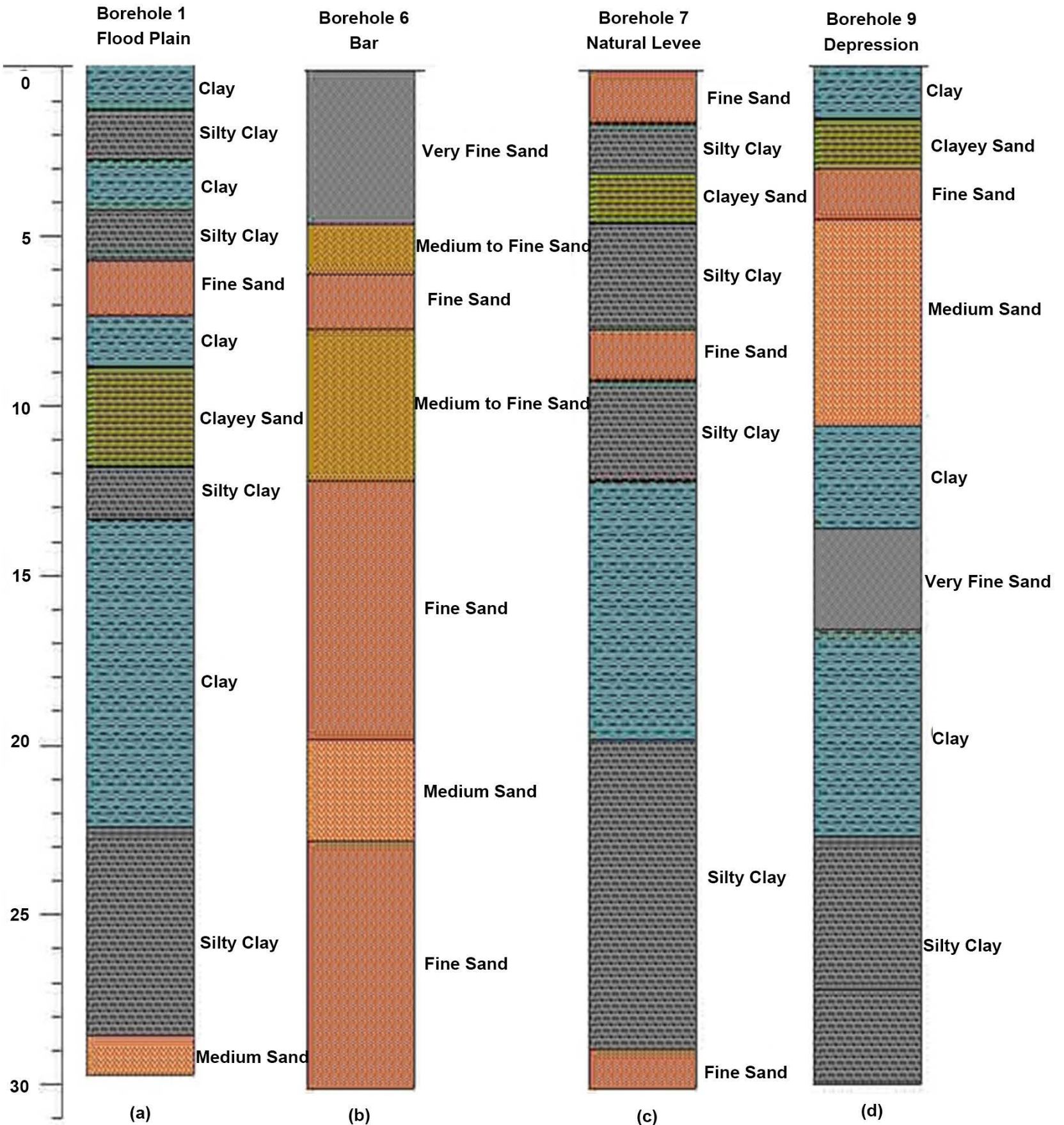

Figure 4. Borehole sections on flood plain (a), bar deposits (b), natural levee deposits (c), and depression deposit (d).

or back swamp deposits. Some natural levees boarder abandoned channels and flood channels that are now less active than when the levees formed (Figure $4(c))$.

Again flood plain deposit mainly comprises with clay, silty clay, clayey silt, sandy silt and fine to medium sand. Silty clays are light olive grey to reddish brown, sticky, plastic in nature. Sands are fine to medium grained, olive grey to dark greenish grey, micaceous (Figure 4(a)). The amount of mica and iron con- 
cretion is about $5 \%$. Medium grained sands are found at 28 to $30 \mathrm{~m}$ depth. The average thickness of this unit is $3 \mathrm{~m}$. Clays are light bluish gray to dark greenish grey, soft, plastic, mottled, hard in dry condition and thickness are ranges from 2 - $4 \mathrm{~m}$. Organic matter is present within the clay. Sticky Clays are moderately reddish brown to pale orange in color and plastic in nature. Possibly these clays are washed materials from the adjacent Madhupur Tract. Somewhere Average thickness of this unit varied from $2 \mathrm{~m}$ to $3 \mathrm{~m}$. Geologically it is assumed that moderately compacted sediments of the levee and flood plain deposits are suitable for medium foundation. Flood basin (Figure 5(a) \& Figure 5(b)) and depression deposits (Figure 4(d), Figure 5(c) \& Figure 5(d)) are consist of alternating clayey silt, silt clay, and very fine to fine sand. Clayey silt is bluish grey to grey in color, presence of partially decomposed organic matter with $2 \%-3 \%$ mica. The percentage of silt and clay are about $75 \%$ and $25 \%$. The thickness of this bed ranges from $4-5 \mathrm{~m}$ in flood basin whereas grey to yellowish brown silty clay contain organic matter. Burrows are observed in this bed.

\subsubsection{Younger Flood Plain Deposits}

The north eastern part of the Brahmaputra covered with Younger Flood Plain Deposit consists of mainly unconsolidated sediments. Frequent changes of the main courses of old Brahmaputra lead to develop a bar complex and latterly subsequent inundation form some flood plain on the bar deposits in the north eastern part of the river. This flood plain is comparatively lower than the older flood plain along the south western bank of the river. The younger flood plain consists of mostly fine to medium grained sands with some silt and clay.

Bar deposits mainly consist of alteration of very fine sand to medium sand intercalated with silt. Very fine to fine sands are light brownish grey in color, rounded to sub rounded, slightly oxidized. Medium sands are light greyish brown in color. Silts are grayish brown in color with some clay. Rootlets and iron patches are observed in silt layer (Figure 6(a)). This deposits are loosely compacted which is not suitable for heavy foundation.

The natural levee deposits (Figure 6(b) \& Figure 6(c)) consist of more or less $2 \mathrm{~m}$ thick medium to coarse sand followed by 0.5 to $1.0 \mathrm{~m}$ thick medium sand, fine sand, very fine sands and silty clay upward. Sands are yellowish brown in color with mica and iron concentrations in it; the percentage is about $5 \%-10 \%$ and $5 \%-15 \%$ respectively. Silty clay is light olive grey in color. Deposits are as thick as 3 to $5 \mathrm{~m}$ adjacent to the channel and thin outward to merge into flood plain (Figure 6(d) and Figure 6(e)), flood basin or back swamp deposits. Some natural levees boarder abandoned channels and flood channels that are now less active than when the levees formed.

The flood plain sequences of the new flood plain deposits mainly consist of fine to medium sand which is light grey to brown in color, sub angular to sub rounded and well sorted. Flood plain deposits have fining upward sequence of silty sand, silty clay and clayey silt. Clayey silts are dark grey, oxidized moderately compact. Rootlets are observed in it. Silty sands and silty clays are pale 


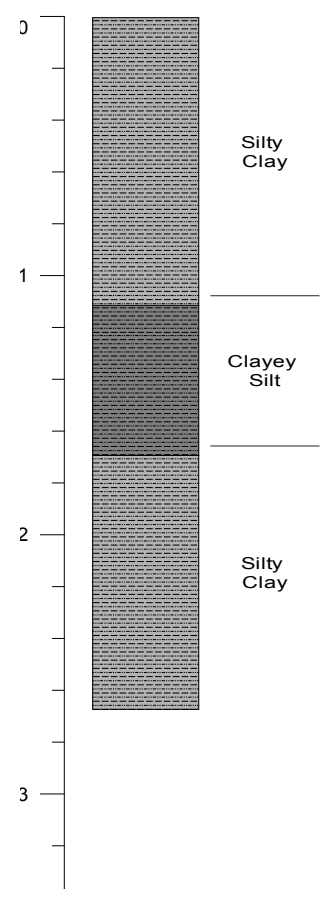

(a)

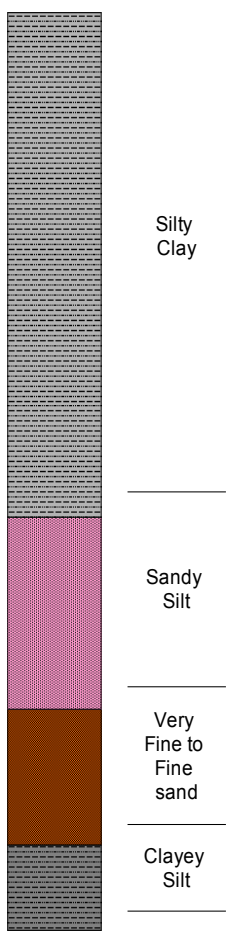

(b)

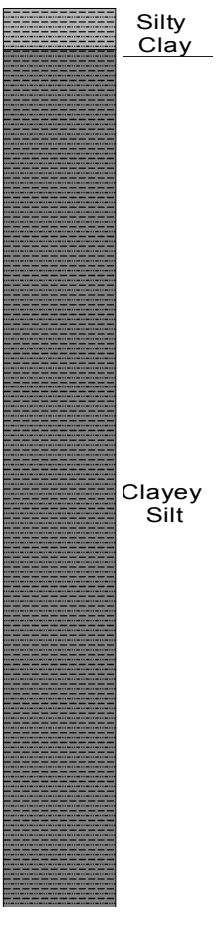

(c)

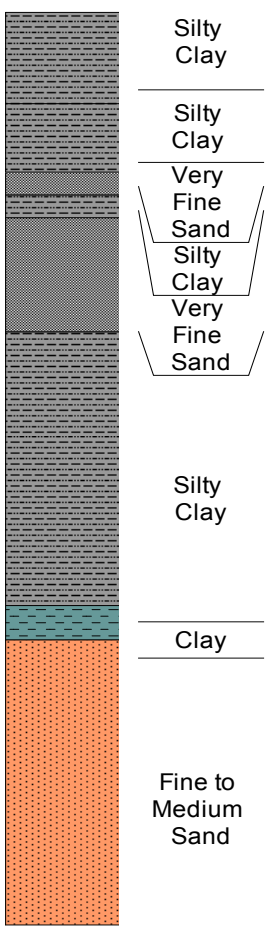

(d)

Figure 5. Measured section in flood basin (a) \& (b) and depression deposits (c) \& (d) of older flood plain deposits.

brown and bluish grey colored; clays are sticky and moderately compacted with the presence of organic matter (Figure 6(d) \& Figure 6(e)). Based on the sediments types, it has been observed that levee and flood plain deposits are loosely compacted.

Abandoned channel deposit is mainly consisting of fine sand at the bottom followed by very fine sand and silty clay on top. Fine sands are dark greenish grey to moderate yellowish brown in color with 5\% - 10\% mica. Very fine sands and silty clays are dark greenish grey colored having more or less $5 \%$ mica and iron concentration (Figure 6(f)). Unconsolidated sands of these deposits are not suitable for heavy foundation.

\subsection{Engineering Geological Analyses}

Engineering geological map (Figure 7) is mainly based on geology, geomorphology and geotechnical characteristics of soil of the area. In most cases, similar sediments/rocks types are grouped into one unit. In some cases, similar sediments/rocks types but specifically different geomorphology is also classified into different units. $\mathrm{N}$-value are determined for each unit by standard penetration test (SPT) boring up to 30 meters and some geotechnical laboratory tests of collected samples were done.

In this investigation, 20 borehole logs have been prepared. Based on physical properties, homogeneity and geotechnical behavior of sediments, the study area is classified into four engineering geological units. 


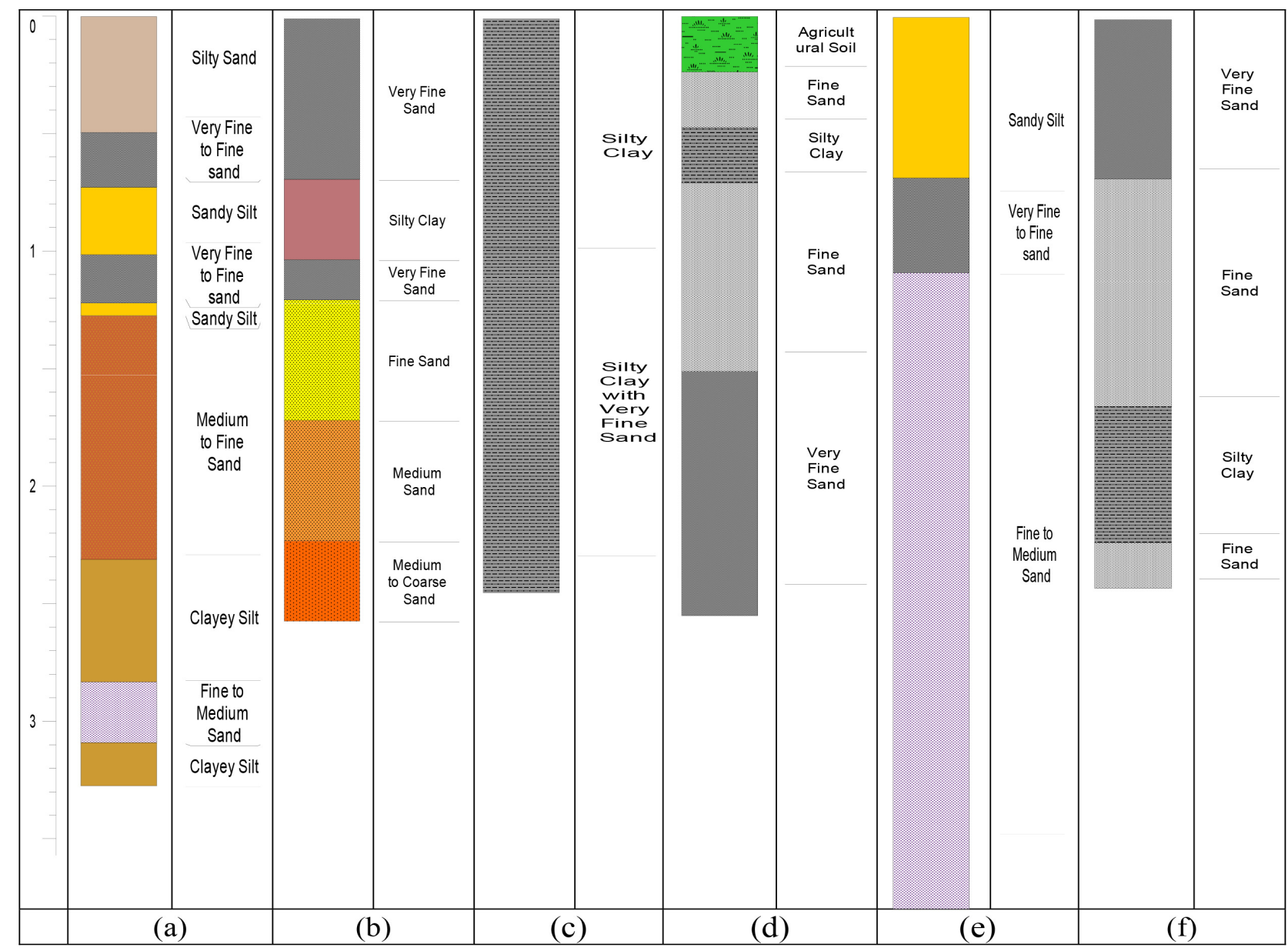

Figure 6. Measured sections of bar deposit (a), natural levee deposit (b) \& (c), flood plain deposit (d) \& (e) and abandoned channel deposit (f) of younger flood plain deposits.

\subsubsection{Unit-I}

This unit consists of irregular ridge like natural levee and relatively broad and more or less flat floodplains of Older Floodplain Deposits. Geotechnical data are obtained from 11 bore logs located on flood plains and natural levees of older flood plain deposits. The subsurface geology mainly composed of fine sand to medium sand, clay and silty clay. Grain size analysis up to 30 meters indicates that the percentage of sand ranges from $2 \%$ to $96 \%$, silt $4 \%$ to $90 \%$ and clay $1 \%$ to $50 \%$. Natural moisture content ranges from $19.22 \%$ to $42.88 \%$. Liquid limit (LL), plastic limit (PL) and plasticity index (PI) of this unit ranges from $34.5 \%$ to $87 \%, 17 \%$ to $35.55 \%$ and $5.5 \%$ to $21.96 \%$ respectively. It is medium to high plastic with an average specific gravity of 2.62 .

The standard penetration test (SPT) values collected from 11 boreholes are summed up. The results show that the $\mathrm{N}$ values range from 5 to 10 up to 20 meters approximately indicate loose soil with a relative density $20 \%-40 \%$; suitable for shallow foundation. Then $\mathrm{N}$-value increases with depth. The maximum $\mathrm{N}$ value found at borehole BH5 \& BH12 are 60 at $30 \mathrm{~m}$ depth consisting of dense to very dense sand and good for heavy foundation. 


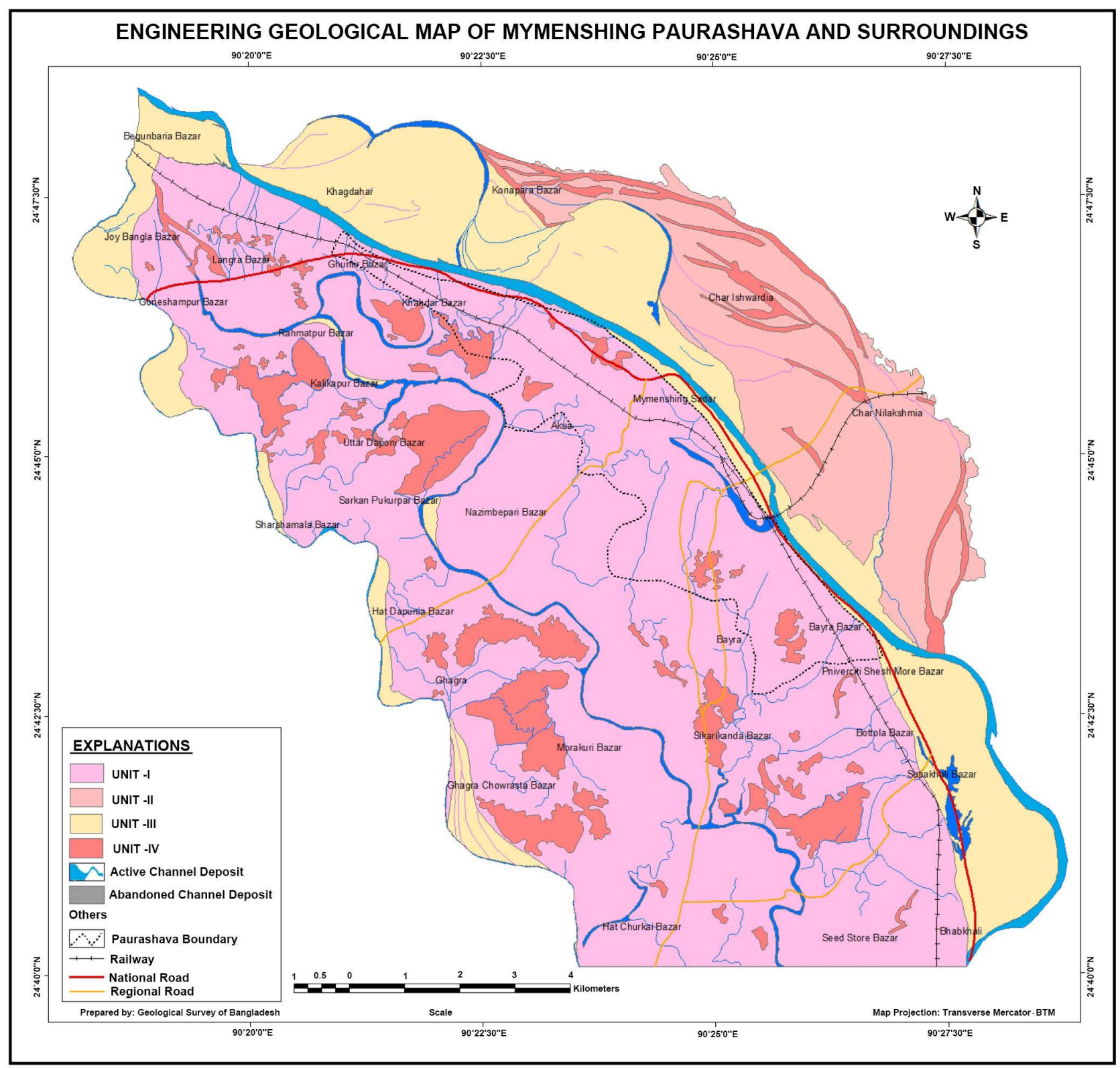

Figure 7. Engineering geological map of Mymensingh Pourashava and adjoining areas.

\subsubsection{Unit-II}

This unit comprises of flood plain deposits and natural levees of younger flood plain deposits. Geotechnical data of Unit-II obtained from bore logs BH 18 \& 20 of younger flood plain deposits of the study area. Important deposits are fine to medium sand, silty clay. Natural moisture content ranges from $22.21 \%$ to $29.76 \%$. Grain size analysis up to 30 meters indicates the sand percentage range from $12 \%$ to $98 \%$, silt $2 \%$ to $47 \%$ and clay $2 \%$ to $41 \%$. Natural moisture content at $15 \mathrm{~m}$ depth of silty fine sand is $22.21 \%-29.76 \%$. Average specific gravity is 2.63. Direct shear analysis up to $20 \mathrm{~m}$ demonstrate that the angle of internal friction range from 29.86 to 30.16 with related cohesion range 8.3 to $18.33 \mathrm{kpa}$.

The standard penetration test (SPT) values collected from boreholes BH 18 \& 
20 are summed up. The $\mathrm{N}$ values range from 10 to 20 up to 20 meters indicating compact soil packing, which increases with depth. The maximum $\mathrm{N}$ value is 40 that found at $30 \mathrm{~m}$ depth consisting of medium to dense sand. This unit would be good for moderate foundation.

\subsubsection{Unit-III}

This unit comprises of bar deposits. Geotechnical data of Unit-III are obtained from 2 bore logs BH 6 \& 19. Important deposits are very fine to medium sand with micaceous silty clay. Natural moisture content ranges from $23.20 \%$ to $30.16 \%$. Grain size analysis up to 30 meters indicates sand percentages range from $38 \%$ to $80 \%$, silt $20 \%$ to $58 \%$ and clay $9 \%$ to $45 \%$. Liquid limit (LL), plastic limit (PL) and plasticity index (PI) of this unit ranges from $34.5 \%$ to $35 \%, 28.5 \%$ to $34.17 \%$ and $3.5 \%$ to $6.78 \%$ respectively. It is very low plastic. Average specific gravity is 2.62 .

The summed up SPT value illustrates that up to 19 meters depth $\mathrm{N}$ value range from 1 to 5 indicating very loose to loose soil packing. This soil is not suitable for heavy foundation. The $\mathrm{N}$-value then gradually increases a little bit with depth. At 30 meters depth it shows the maximum SPT value which is 35; indicates medium to dense packing of soil could be used as moderate foundation.

\subsubsection{Unit-IV}

This unit comprises of flood basin, depression abandoned channel deposits. Important deposits are clay, silty clay, sandy clay and very fine to medium sand with organic matters. Geotechnical data of Unit-IV obtained from bore logs $\mathrm{BH}$ 9, 11, 15 \& 17 of different sites of Mymensingh urban plan area. Grain size analysis up to 30 meters indicates that sand percentage range from $0 \%$ to $96 \%$, silt 4 to $83 \%$ and clay $0 \%$ to $50 \%$. Natural moisture content ranges from $19.03 \%$ to $34.36 \%$. Liquid limit, plastic limit and plasticity index of this unit range from $35 \%$ to $55 \%, 24.42 \%$ to $32.15 \%$ and $5.58 \%$ to $26.45 \%$ respectively it is medium to highly plastic with an average specific gravity of 2.41 .

The interpretation of $\mathrm{N}$ values are figured out that the $\mathrm{N}$ value ranges from 5 to 15 up to $20 \mathrm{~m}$ depth signifying loose packing of soil; then increases to 45 found at approximately $25 \mathrm{~m}$ depth in fine sand sediments. The abrupt decreases of $\mathrm{N}$-value ( 1 to 10 ) at around $30 \mathrm{~m}$ depth are observed where the sediments consist of compressible organic clay. These would be risk for heavy foundation.

\section{Conclusions and Recommendation}

The present study is on geomorphologic, geologic and engineering geological parameters which are very much crucial to be considered prior to any urban planning. Lack of such adequate data during planning and early stages of site investigations for specific urban structure e.g. building, bridges, roads, utility supply systems, etc. leads to significant damages and failure of structures, cost derived reparations of the structure and reclamation of the natural environment. 
Mymensingh could be a great urban area if an urban planner considers and values these data and takes appropriate engineering measures where necessary.

Old flood plain and natural levee areas are composed mainly of silty sand and sand which are mainly the washed sediments of adjacent Madhupur Tract formation having high $\mathrm{N}$ value could be appropriate for heavy structure. In addition, older flood plain is comparatively elevated than Younger flood plain. Sediments are more compacted in Old flood plain compared to Younger flood plain area as well which could be considered as the suitable place for constructing any structure. On the other hand, in Younger flood plain sandy sediments are mainly very fine to medium; geotechnically, these very fine sands are very loose to loose in nature having $\mathrm{N}$-value ranges from 2 to 10 . Medium sands are characterized as dense to very dense sand having $\mathrm{N}$-value 29 to 50 . These areas are suitable for shallow structures. Some depressions are found in older flood plain. It is recommended to avoid development and expansion of the city towards areas of depression covered by black organic clay deposits and in the areas of new bar deposit along the north eastern part of Brahmaputra River. These depressions including flood basin and abounded channel could be used as open place, park or site for playground with light structures or as water retaining zone.

The city is located near two of the strong seismic source i.e. Dauki Fault on the north and Madhupur fault on the south. A systematic study is recommended on seismic hazards. The planning of urban development based on the micro zoning maps and probable earthquake scenarios would decrease the probable earthquake damages. In the planning and the design of new settlement areas and the environment with current settlement, every stage of the plan geological data is required for the reduction of urban earthquake risks. In the process of creating earthquake resistant safe cities, geophysical survey and micro zoning mapping along with geological and geotechnical investigations play key role in the integration of hazard mitigation precautions to planning.

As the study area is bounded by the Brahmaputra on the north eastern part and Sutia and Barrera, the distributaries of Brahmaputra River on the south west part are the major sources of water supply. Apart from this there are many Bils (perennial lakes) on the flood basin and depressions which could be a good source of surface water. Ground water table are encountered between $0.66 \mathrm{~m}$ to $4.75 \mathrm{~m}$. Water logging is a common phenomenon in the Mymensingh Pouroshava areas. In general, a good internal drainage system of the study area should be constructed following the natural slope of the area and will have provisions to connect the adjacent river. Drainage system of the area will be synchronized to avoid water logging inside the area. The existing ground of the low area should be raised above the flood level of 1998 flood; not disturbing the natural water flow.

Development of a systematic multidisciplinary database aided by Geographic Information system (GIS), with continuous monitoring and updating of data is also highly recommended and will be useful for rational planning further refined of the planning of the city. 


\section{Acknowledgements}

The study was financially supported by the Comprehensive Disaster Management Program under the Ministry of Relief and Disaster Management of Bangladesh through UNDP grant. The authors are very grateful to the Director General of Geological Survey of Bangladesh for providing logistic and administrative support to conduct fieldwork. The technical support extended by the Geospatial Solution for geotechnical laboratory for analyzing soil samples is dully acknowledged.

\section{References}

[1] Berhane, G. and Walraevens, R. (2012) Geological and Geotechnical Constrains for Urban Planning and Natural Environment Protection: A Case Study from Mekelle City, Northern Ethiopia. Environmental Earth Sciences, 69, 783-798. https://doi.org/10.1007/s12665-012-1963-x

[2] Anderson, F.J. (2006) A Highlight of Environmental and Engineering Geology in Fargo, North Dakota, USA. Environmental Geology, 49, 1034-1042.

https://doi.org/10.1007/s00254-005-0142-8

[3] Bathrellos, G.D., Skilodimou, H.D., Kelepertsis, A., Alexakis, D., Chrisanthaki, I. and Archonti, D. (2008) Environmental Research of Groundwater in the Urban and Suburban Areas of Attica Region, Greece. Environmental Geology, 56, 11-18. https://doi.org/10.1007/s00254-007-1135-6

[4] Bathrellos, G.D., Gaki-Papanastassiou, K., Skilodimou, H.D., Papanastassiou, D. and Chousianitis, K.G. (2011) Potential Suitability for Urban Planning and Industry Development Using Natural Hazard Maps and Geological-Geomorphological Parameters. Environmental Earth Sciences, 66, 537-548. https://doi.org/10.1007/s12665-011-1263-x

[5] De, Abreu, A.E.S. and Filho, O.A. (2011) Engineering Geological Data in Support of Municipal Land Use Planning: A Case Study in Analandia, Southeast Brazil. Environmental Earth Sciences, 65, 277-289.

[6] Legget, R.F. (1973) Cities and Geology. McGraw Hill, New York.

[7] Pueyo-Anchuela, O., Casas-Sainz, A.M., Pocovi, J.A. and Anson-Lopezo, D. (2011) Multidisciplinary Approach for Urban Planning in Alluvial Karstic Zones. Case study from the Central Ebro Basin (Spain). Engineering Geology, 122, 222-238. https://doi.org/10.1016/j.enggeo.2011.05.016

[8] El May, M., Dlala, M. and Chenini, I. (2010) Urban Geological Mapping: Geotechnical Data Analysis for Rational Development Planning. Engineering Geology, 116, 129-138. https://doi.org/10.1016/j.enggeo.2010.08.002

[9] Culshaw, M.G. and Price, S.J. (2011) The Contribution of Urban Geology to the Development, Regeneration and Conservation of Cities. Bulletin of Engineering Geology and the Environment, 70, 333-376. https://doi.org/10.1007/s10064-011-0377-4

[10] Alam, A.K.M.K., Coates, D.A., Mannan, K.H., Ahmed, D. and Hossain, S. (2008) Geology of Parts of Tangail and Mymensingh Districts, Bangladesh. Records of the Geological Survey of Bangladesh, 11, 5.

[11] Seeber, L. and Armbrewster, J. (1981) Great Detachment Earthquakes along the Himalayan Arc and Long-Term Forecasts. In: Simpson, D.W. and Richards, P.G., Eds., Earthquake Predication and International Review, Maurice Ewing Series 4, 
American Geophysical Union, Washington DC, 259-277.

[12] Coleman, J.M. (1969) Brahmaputra River: Channel Processes and Sedimentation. Sedimentary Geology, 3, 129-239. https://doi.org/10.1016/0037-0738(69)90010-4 